\title{
Technological processes of reusing crushed concrete in the demolition of buildings in construction
}

\author{
Vladimir Efimov ${ }^{1, *}$, Denis Pogodin ${ }^{1}$, and Myhammet Fakhratov $^{1}$ \\ ${ }^{1}$ Moscow State University of Civil Engineering, Yaroslavskoe shosse, 26, Moscow, 129337, Russia
}

\begin{abstract}
The paper is dedicated to waste processing management in waste processing technology. Processing of scrap concrete waste, similar in composition and condition to traditional raw materials, is economically and ecologically feasible. Secondary crushed stone obtained by crushing scrap of reinforced concrete panels in demolished five-storey apartment blocks of the first phase was studied. It is shown that concrete with scrap concrete waste shows strength properties similar to primary concrete and helps organize waste-free production. The methods of recycled waste usage, especially usage of secondary crushed stone made of crushed concrete scrap, are becoming ever more relevant with every passing year. Imported concrete aggregate volumes can be reduced by $15-30 \%$ due to usage of secondary crushed stone. Consideration of industrial waste problem and methods of solving this problem by using waste in construction industry, including secondary crushed stone made of crushed concrete scrap, is made. Annually, about 11.5 million tons of construction waste is generated in Moscow. The use of industrial waste similar in terms of composition and condition of traditional raw materials unquestionable from economic and environmental point of view. This study showed that concrete using fine granulated blast furnace slag as cement additives has higher initial strength characteristics.
\end{abstract}

\section{Introduction}

Construction waste in Moscow is generated as a result of demolition and reconstruction of buildings and structures, while producing construction materials, details and components; after utility systems reconstruction etc.

Waste volumes generated by five-storey typical apartment buildings clearance (first period of prefabricated construction), account for the bulk of total balance of construction waste producing in the city. Further, more than 4 million $\mathrm{m} 2$ of new buildings are built annually, road construction works produce about 90 million $\mathrm{m} 2$ of extracted soil and asphalt, up to 22 thousand $\mathrm{m} 2$ of apartment are repaired by residents, large amount of works is done to overhaul housing stock.

For the moment, most of the produced construction waste in Moscow is transported to landfills and dump sites, including unauthorized landfills, located within the city limits and

\footnotetext{
*Corresponding author: efimov1234@mail.ru
} 
in the Moscow region, which adversely affects ecology in the entire Moscow region. While construction waste is a secondary raw material, its usage after processing into secondary crushed stone and sand and crushed stone mix can reduce costs for new urban building, reduce the load on municipal landfills, exclude formation of unauthorized landfills, and preserve land resources currently used as landfill zones to construct, for example, parks.

Due to the lack of natural aggregates, the expansion in the number of old worn-out concrete buildings subject to demolition, and the need to comply with environmental protection requirements, great attention was paid to the problem of concrete utilization in the construction industry in the USSR during the 70s. However, to reach expected great volume of crushed stone and sand, produced from crush products of concrete and reinforced concrete elements, it requires codes and standards, which specify certain requirements for new types of products.

England and Germany concrete scrap, produced during WWII, was used as big aggregate while producing concrete mixture. In some countries (Japan, Denmark, Luxembourg, etc.) there are practically no territories for landfill sites or utilization grounds for concrete scrap. Large scale experiments to study the properties of secondary aggregates and concretes on their base have been made in Japan since 1974. The USA have many years of experience in concrete utilization. For more than 10 years over 20 million tons of concrete waste has been processed annually. According to a number of the American manufacturers, during processing concrete into crushed stone fuel consumption is 8 times as low as during its natural production, the cost of concrete with secondary crushed stone being lower by $25 \%$. The annual volume construction and demolition waste production (CDW) in Moscow is about 7 million tons today and shows increasing tendency.

The demolition of 5.100 five-story apartment blocks in Moscow will start in early 2018. In fact, they resemble the five-story apartment blocks demolished in the city over the past 20 years, during which the first phase of demolition has been implemented. It was decided to demolish buildings of 1-515, 1-510, 1-511, 1-447 series starting in 2018.

About 53 million tons of construction waste will be produced after closure of the renovation program. It is planned to process up to $100 \%$ of construction waste, under demolishing the capital's five-storey apartment blocks as part of the renovation program.

In this article, based on the analysis of domestic and foreign experience, the optimal technological schemes for the processing of construction waste are given, the existing equipment is described, its advantages and disadvantages are discussed, the possibility and expediency of its use are given, the technological and economic characteristics and recommendations for the products of construction waste processing are given.

\section{Materials and methods}

Analysis of experimental data obtained both in Russia and abroad showed deterioration of serviceability of concretes obtained with the use of crushed concrete as a fine aggregate (in crusher-run-stone aggregate fractions less than $5 \mathrm{~mm}$ to $30 \%$ ). The effectiveness of the use of crushed concrete as a large aggregate is beyond doubt.

The following quality indicators should characterize crushed stone as a large aggregate for heavy concrete: grain composition, grain form, crushing capacity, impurity content, and density (real, average, poured), porosity, voidness and water absorption, which are determined in accordance with GOST 8269-87. Special requirements for crushed stone's frost-resistance may not be presented. The content of impurities in crushed stone in the form of lime plaster, gypsum, organic inclusions, etc. should not exceed $1 \%$ by weight. Based on the analysis of domestic and foreign experience, it can be concluded that the secondary crushed stone after processing of concrete is recommended to use: a) during construction of an underlayer of driveways and by-pass roads; and foundations for storage 
and industrial facilities and small mechanisms; b) for the construction of groundwork base or topping of sideways, parking lots and promenade alleys, as well as slopes along rivers and canals. The material, undergone processing concrete, can also be used for concrete mixing, which is quite suitable for covering sideways, rural roads and inner garage territory, as well as in the factory production of reinforced concrete products with density up to $30 \mathrm{MPa}$ or class B 22.5.

Studying physical and mechanical properties of concretes from concrete scrap waste, it was concluded that they are equal to normal-weight concretes with natural crushed stone. In these concretes, F225 frost-resistance grade and high values when calculating Poisson's ratio (0.2) were achieved. Also, the concrete showed high results in the adhesion between reinforcement and concrete $(13 \mathrm{MPa})$.

Using concrete scrap waste in building concrete and reinforced concrete products and structures, mankind solves several problems at once: saving energy and natural resources, as well as capital investments; reduction of dumps and litter-free territories; non-waste production of concrete and reinforced concrete products, of repair works, of reconstruction and demolition of old buildings etc. This is certainly the right way for both man and environment. But insufficiency of processing methods and technologies throws back the process of wider use of concrete scrap waste. Concerning the economic side of the issue, it is noted that concrete with aggregates made of concrete scrap waste is cheaper than concrete with natural aggregate.

Taking the above into account, it is advisable to add values for the Poisson's ratio, for adhesion between concrete and reinforcement, for brand, for frost-resistance of secondary crushed stone in SNiP (GOST) for the introduction of secondary crushed stone into the production of concrete and reinforced concrete products and structures, which can solve many problems. As a result, adding aggregates of the above mentioned, we obtain concrete with high performance property (for lifetime, waterproofness, frost-resistance, chemical resistance, durability and bending resistance and compression breaking strength), with high early strength for prefab reinforced concrete with early timbering and shorter construction times; as well as conveyed concrete of best properties for conveying and placing, with reduced water demand, ensuring wear-reduction of the conveying equipment.

\section{Results}

Secondary crushed stone, obtained by crushing scrap of reinforced concrete panels in demolished five-storey apartment blocks of the first phase, was investigated. In the fine fraction of secondary crushed stone, there is not enough primary aggregate, while the fractions of 10-20 and $20-40 \mathrm{~mm}$ are approximately equal in their ratio of aggregates and binder. There is more than half of concrete mortar in such crushed stone. It is established that the frost-resistance of crushed stone of concrete corresponds to the frost-resistance class from F15 to F125, depending on fraction.

Homogeneity evaluation of crushed stone by average density and crushability showed that the variation coefficient is equal to $8 \%$.

Secondary crushed stone has best efficiency ratio if concrete and reinforced concrete scrap:

- is delivered, processed and stored free from admixture, that means concrete-to-crushed stone process is cleared from bobs and other contaminants

- underwent two-stage processing in grinder, that means weak mortar phase was maximally removed from crushed stone by grinding screening processes.

The physical and chemical properties of concrete scrap aggregates are presented in Table 1. 
5-10 $\mathrm{mm}$ fracture comparative study, based on the results of the research, was earned out . The results of the study are presented in Table 2 .

It follows that secondary crushed stone can be used as concrete aggregate, since the specified requirements for heavy concrete's crushed stone according to GOST 8267-93 arc observed.

After analyzing secondary crushed-stone concrete of crushed concrete, we selected and tested various mixtures with different cement-water ratios and different fluidity values in Table 3 .

Table 1. Concrete aggregators properties.

\begin{tabular}{|c|c|c|c|c|}
\hline Fraction & $\mathbf{5 - 1 0}$ & $\mathbf{5 - 2 0}$ & $\mathbf{1 0 - 2 0}$ & $\mathbf{2 0 - 4 0}$ \\
\hline Properties & 2.52 & 2.53 & 2.55 & 2.53 \\
\hline $\begin{array}{c}\text { Aveal density }\left(\mathrm{g} / \mathrm{m}^{3}\right) \\
\left(\mathrm{g} / \mathrm{m}^{3}\right)\end{array}$ & 2.13 & 2.16 & 2.21 & 2.26 \\
\hline $\begin{array}{c}\text { Poured density } \\
\left(\mathrm{g} / \mathrm{m}^{3}\right)\end{array}$ & 1.34 & 1.32 & 1.33 & 1.36 \\
\hline Porosity (\%) & 15.48 & 14.62 & 13.33 & 10.67 \\
\hline Void Content (\%) & 37.1 & 38.89 & 39.82 & 39.82 \\
\hline $\begin{array}{c}\text { Water absorption } \\
(\%)\end{array}$ & 7.9 & 5.8 & 3.7 & 2.5 \\
\hline Humidity (\%) & 3.5 & 3.5 & 3.6 & 3.6 \\
\hline
\end{tabular}

Table 2. Natural crushed stone and secondary crusched stone comparison according to physicalmechanical properties.

\begin{tabular}{|c|c|c|c|c|}
\hline Properties & $\begin{array}{c}\text { Crushed stone } \\
\text { of consolidated } \\
\text { rock (gravel) }\end{array}$ & $\begin{array}{c}\text { Secondary } \\
\text { crushed stone }\end{array}$ & $\begin{array}{c}\text { Crushed stone } \\
\text { of porous rock }\end{array}$ & $\begin{array}{c}\text { Expanded } \\
\text { pearlite } \\
\text { crushed stone }\end{array}$ \\
\hline $\begin{array}{c}\text { GOST } \\
\text { requirements }\end{array}$ & $8267-93[4]$ & - & $22263-76[5]$ & $10832-91[6]$ \\
\hline Average density & 2.65 & 2.13 & 2 & 2.05 \\
\hline $\begin{array}{c}\text { Durability class } \\
\text { according to } \\
\text { crushability }\end{array}$ & 1000 & 400 & 400 & 400 \\
\hline $\begin{array}{c}\text { Content laminar } \\
\text { and needle- } \\
\text { shaped grains \% }\end{array}$ & 9.4 & 40 & 30 & 25.5 \\
\hline $\begin{array}{c}\text { Flour and clay } \\
\text { particles }\end{array}$ & 0.4 & 2.5 & 2.7 & 2.5 \\
\hline $\begin{array}{c}\text { Frost-resistance, } \\
\text { cycles }\end{array}$ & 200 & 25 & 15 & 25 \\
\hline $\begin{array}{c}\text { Water } \\
\text { absorption \% }\end{array}$ & 4 & 7.9 & 9.45 & 7.5 \\
\hline
\end{tabular}

Table 3. Composition and basic physical characteristics of concrete with secondary crushed stone.

\begin{tabular}{|c|c|c|c|c|c|}
\hline \multirow{2}{*}{$\mathbf{N}$} & Specification & Unit of & \multicolumn{3}{|c|}{ Structure code } \\
\cline { 3 - 5 } & & measurement & Test & A-1 & A-2
\end{tabular}




\begin{tabular}{|c|c|c|c|c|c|}
\hline & & & specimen & & \\
\hline 1 & $\begin{array}{l}\text { Consumption of } \\
\text { materials per } 1 \mathrm{~m}^{3} \text { of } \\
\text { concrete mix }\end{array}$ & & & & \\
\hline 1.1 & Cement & $\mathrm{kg}$ & 330 & 540 & 392 \\
\hline 1.2 & $\begin{array}{l}\text { Secondary crushed } \\
\text { stone fracture } 5-20 \\
\mathrm{~mm}\end{array}$ & $\mathrm{~kg}$ & - & 960 & 1011 \\
\hline 1.3 & $\begin{array}{l}\text { Natural crushed stone } \\
\text { GOST } 8276-93\end{array}$ & $\mathrm{~kg}$ & 980 & - & - \\
\hline 1.4 & Sand & $\mathrm{kg}$ & 852 & 590 & 708 \\
\hline 1.5 & Water & $\mathrm{kg}$ & 165 & 210 & 187 \\
\hline 1.6 & $\mathrm{C}-3$ & $\mathrm{~kg}$ & - & - & 2.17 \\
\hline 2 & Cement-water ratio & - & 0.41 & 0.39 & 0.48 \\
\hline 3 & Fluidity of concrete & $\mathrm{cm}$ & $6-8$ & $6-7$ & $6-8$ \\
\hline 4 & Fluidity class & - & $\mathrm{P} 2$ & $\mathrm{P} 2$ & $\mathrm{P} 2$ \\
\hline 5 & $\begin{array}{l}\text { Average density of } \\
\text { concrete mix }\end{array}$ & $\mathrm{Kg} / \mathrm{m}^{3}$ & 2327 & 2300 & 2300 \\
\hline 6 & $\begin{array}{c}\text { Strenght of } \\
\text { compression at age } \\
7 \text { days } \\
28 \text { days }\end{array}$ & $\mathrm{Mpa}$ & $\begin{array}{l}27.1 \\
36.9\end{array}$ & $\begin{array}{l}25.4 \\
35.3\end{array}$ & $\begin{array}{l}25.4 \\
35.3\end{array}$ \\
\hline 7 & $\begin{array}{c}\text { Bending resistance at } \\
\text { age } \\
7 \text { days } \\
28 \text { days }\end{array}$ & $\mathrm{Mpa}$ & $\begin{array}{l}2.8 \\
3.9\end{array}$ & $\begin{array}{l}2.6 \\
3.6\end{array}$ & $\begin{array}{l}2.6 \\
3.6\end{array}$ \\
\hline 8 & $\begin{array}{l}\text { Class of compression } \\
\text { breaking strength }\end{array}$ & - & $\mathrm{B} 25$ & B25 & B25 \\
\hline
\end{tabular}

Compositions are given in the Table 3. Physical characteristics of concrete with secondary crushed stone are equal to concrete GOST 25192-82*, GOST 26633-91*. This said, if we track strength gain in concrete with secondary crushed stone with time, we see that initially less resistant concrete in early stages in time is becoming equal in time to concrete with natural aggregate. As a result of studying physical and mechanical properties of concretes with secondary crushed stone, it is clear that these concretes are equal to those of normal-weight concrete with natural crushed stone. Frost-resistance of such concrete reached F200, the adhesion between reinforcement and concrete - $13 \mathrm{MPa}$. If we track strength gain of concrete with secondary crushed stone for a period of time, it can be seen that the concrete (1) and (2), that was initially less durable in early stages, is becoming equal in time to concrete (2) with natural aggregate, and concrete with agent C-3 shows excellent results. Studying physical and mechanical properties of concretes with secondary crushed stone, it is clear that these concretes are equal to those of normal-weight concrete with natural crushed stone.

\section{Conclusions}

Increasing utilization of construction and demolition waste will also reduce the destructive impact on the source of raw materials; in the future it is necessary to increase the use of 
concrete scrap as a component for the production of concrete and reinforced concrete. Reinforced concrete upgrades the quality of buildings constructed. Buildings, made of reinforced concrete structures, have high physical properties, such as sound insulation, fire and thermal characteristics. These qualities are achieved without using additional materials.

Mass construction of such buildings increases residents' safety from destruction under external and environmental influences. Ultimately, in order to maintain such a positive impact, we have to build more durable buildings that will last 150-200 years, rather than 5060 years, as it was during the construction of five-storey apartment blocks of the first phase.

Based on the research conducted, the materials in question were put into production at 'Khoroshevsky 'DSK-1' Precast Concrete Plant, 50m2 of reinforced concrete palettes for three-dimensional utility block were produced. $100 \mathrm{~m} 2$ of reinforced balcony plates were produced at 'Rostokinsky 'DSK-1' Precast Concrete Plant, $100 \mathrm{~m} 2$ of reinforced inner wall plates were produced at 'Krasnopresnensky 'DSK-1' Precast Concrete Plant. All products passed quality control tests and were delivered to construction sites for to construct a P44TM series block of flats.

Construction waste and waste from demolished worn-out five-storey buildings is a topic that should be considered separately, because it is a problem on national level. Necessary to develop unified accounting scheme for waste disposal? And its rational use in future as a resource-energy-saving technology in the production of construction materials and structures

\section{References}

1. Russian Federation Standard GOST 25916

2. O.Sh. Kikava, I.A. Solomin, Utilization of construction waste (Moscow, 2000)

3. Yu.M. Bazhenov, Method for determining the composition of various types of concrete (Moscow, 1975)

4. Russian Federation Standard, GOST 8267

5. Russian Federation Standard, GOST 25192

6. Russian Federation Standard, GOST 26633

7. M.A. Fakhratov, E.V. Kalmykova, Effective use of crushed concrete waste in the production of concrete and reinforced concrete products. Management of investment and construction and housing and utilities complex: International Collection of Scientific Works (Moscow State Academy of Municipal Economy and Construction, Moscow, 2010)

8. M.A. Fakhratov, V.I. Sokhryakov, E.V. Kalmykova, A.A. Belov, Magazine for Professionals StroyProfil 7(98) (2012)

9. A.A. Kalchin, M.A. Fakhratov, O.Sh. Kikava, V.V. Baev, Industrial waste in the production of building materials. Manual for graduate students (ZAO Publishing house "Elite", Tver, 2002) BBK 38.626.2 to 61 ISBN-12-2

10. M.A. Fakhratov, Magazine Building materials 12, 48-49 (2003)

11. A.A. Kalgin, M.A. Fakhratov, E.V. Kalmykova, A.N. Kravchenko, International Concrete Production Magazine 2 (2008)

12. Kalgin A.A., Fakhratov M.A., Sokhryakov V.I., Belov A.A., Efficiency of using concrete and reinforced concrete waste with mineral additives in combination with superplasticizers (StroyProfil, OOO 'Rosvalt”, St. Petersburg, 1997) 
13. A.V. Aksenov, SB. Articles "New ideas of development of concrete and reinforced concrete structures" (Moscow, 2002)

14. I.Kh. Nanazashvili, Building materials, products and structures, Handbook (Illuminati Higher school, Moscow, 1990) 